\title{
DESIGNING TRICKLE IRRIGATION SYSTEM WITH PRESSURE COMPENSATING EMITTERS
}

\author{
A.H. Gomaa, A.H. Eissa and Amira A. Abdallah \\ Agriculture Engineering Dept., Menufiya University.
}

Received: Oct. 4,2020

Accepted: Nov. 29,2020

\begin{abstract}
The objective of this study was to design the trickle irrigation system by compensating emitters (Katif) and The experimental work was carried out in the experimental farm of faculty of Agriculture, Menufia university during 2018. A field experiment was conducted for $50 \mathrm{~m}$ and $75 \mathrm{~m}$ of lateral length with outer diameter $16 \mathrm{~mm}$ and $\varphi 13.6 \mathrm{~mm}$ inner diameter under discharges of $(2,4$ and $8 \mathrm{~L} / \mathrm{h})$ and spacing between emitters $0.5 \mathrm{~m}$. Several points were taken $2 \mathrm{~m}$ apart into considerations, such as emitter characteristic friction losses, manufacturing variation, discharge and hydraulic variation. Emitters were tested at $50,100,150$ and $200 \mathrm{kpa}$ to determine the pressure-discharge relationship and the uniformity parameters.

The found results showed that the exponent values for the compensating emitters under study ranged from 0.06 to $\mathbf{0 . 2}$. The measured coefficients of manufacturing variation values for compensating emitters were in the excellent class. As such the variation of discharge through these laterals is restricted by limiting their number to have emission uniformity, EU, greater than $90 \%$.
\end{abstract}

Key words: Trickle irrigation; compensating emitter (Katif); laterals length; emission uniformity; pressure discharge relationship.

\section{INTRODUCTION}

Trickle irrigation system is a system that has been used for long in various parts of the world under different climatic conditions, crop types as well as soil types. It is a type of irrigation that slowly applies small amount of water to part of the plant root zone (McConnell, 2003). It is consider the newest of all methods of irrigation systems in water application. It described as the frequent slow application of water to soil through mechanical devices called emitters, or applicators located at selected points along the water delivery lines. (Jensen, 1993).

Khairy et al., (2016) showed that mobile drip irrigation system have the best results because the efficiency of surface drip irrigation $95 \%$ and the results showed the classification of all used drip tubes were fully pressure compensating .
Trickle irrigation system, to suit the condition of a particular site, is specially designed in order to achieve high efficiencies in its performance and economy. (Jack \& David, 1974)

Early research in drip irrigation design was conducted mostly for a single lateral line (Wu,1992).

Design the trickle irrigation system by compensating emitter can apply water to plants at very low flow rates. This ensures more efficient watering, reducing the risk of over watering or under watering and saving energy by using low pressure and we can use it in designing trickle irrigation system.

The objective of this paper is to design the trickle irrigation system using the pressure compensating emitters (Katif). 
A.H. Gomaa, et al.,

\section{MATERIALS AND METHODS}

The experiments were carried out in Department of Agricultural Engineering laboratory and farm of faculty of Agriculture Menoufia university, during 2018 .

Compensating emitters (katif) with three different flow rates $: 2,4$ and $8 \mathrm{~L} / \mathrm{h}$ at emitters spacing of $0.5 \mathrm{~m}$.

Emitters were tested at 50,100 , 150 and $200 \mathrm{kPa}$ to determine manufacture coefficient of variation $\mathrm{CV}_{\mathrm{m}}, \mathrm{X}$ and $\mathrm{k}$ values using equation 1 and 2. Emitters were connected with the energy of lateral line and measure all variation in the emitter discharge as a result of manufacture's variations and hydraulic variations.

Katif described with flow- regulated self - flushing emitter and prevents water run- off along the drip line.

In this study, there were two drip lines $50 \mathrm{~m}$ and $75 \mathrm{~m}$ (Fig.1), long which are made of Poly Ethylene (PE).

The outer diameter of the lateral line was $16 \mathrm{~mm}$ with $\varphi 13.6 \mathrm{~mm}$ inner diameter and the irrigation line was installed on ground with

Manufacturing coefficient of variation was calculated using equation (1) and its classification are shown in Table (1) for (Bralt et al ., 1987)

$$
\mathbf{c v}_{m}=\frac{s}{q}
$$

Where,

$\mathrm{Cv}_{\mathrm{m}}=$ Manufacturing coefficient of variation

$\mathrm{S}=$ sample standard deviation

$q=$ Average emission rate of sample

\section{Head- discharge relationship}

The head discharge relationships for emitters were expressed by the formula (karmeli, 1977and Wu and Gitlin, 1977)

Where ,

$$
q=K H^{x}
$$

$q=$ Discharge rate of emitters, $\mathrm{L} / \mathrm{h}$.

$\mathrm{K}=$ Discharge Coefficient

$\mathbf{H}=$ Pressure Head, $\mathbf{m}$.

$X=$ Emitter flow exponent

The value of $X$ varies from 0 to 1 for wide range of emitters. If $X$ approaches zero, the drippers are classified as fully pressure compensating and it is, however difficult to achieve in the manufacturing process.

Trickle irrigation is a type of irrigation that slowly at applies small amount of water to part of the plant root zone (McConnell, 2003).

It is consider the newest of all methods of water application. It described as the frequent slow application of water to soil through mechanical devices called emitters, or applicators located at selected points along the water delivery lines (Jensen, 1993).

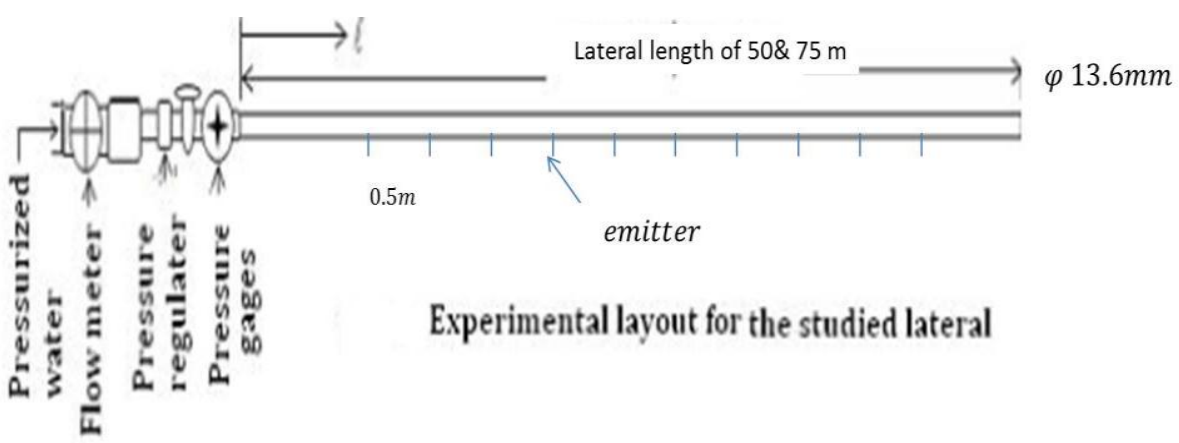

Fig. (1): Experimental lay out for the studied lateral. 
Table (1): Illusterate the calssifican of manufacture's coefficient of variations .

\begin{tabular}{|c|c|c|}
\hline Emitter type & $\mathrm{C}_{\mathrm{v}}$ range & Classification \\
\hline \multirow{4}{*}{ Point source } & $<0.05$ & Excellent \\
\cline { 2 - 3 } & $0.05-0.07$ & Average \\
\cline { 2 - 3 } & $0.07-0.11$ & Marginal \\
\cline { 2 - 3 } & $0.11-0.15$ & Poor \\
\cline { 2 - 3 } & $>0.15$ & Unacceptable \\
\hline \multirow{3}{*}{ Line source } & $<0.10$ & Good \\
\cline { 2 - 3 } & $0.10-0.20$ & Average \\
\cline { 2 - 3 } & $>0.20$ & Marginal to unacceptable \\
\hline
\end{tabular}

\section{RESULTS AND DISCUSSION}

\section{Pressure-Discharge Relationship:}

Results show that the predicted exponential equations for this studied emitters are as follow :

$q=1.9923 * p^{0.211}$ for the katif emitter of $2 \mathrm{l} / \mathrm{h} \quad(3)$

$q=3.6063 * p^{0.177}$ for the katif emitter of 4 I/h (4)

$q=8.3969 * p^{0.067}$ for the katif emitter of 8 $\mathrm{l} / \mathrm{h}$

Where, q: the discharge of emitter in $(\mathrm{l} / \mathrm{h})$.

$P$ : pressure in (bar).

It can be noticed that the emitter discharge exponent values ( $x$-values) varied between 0.067 to 0.211 .
Discharge along the lateral line:

Fig. (2) showed the relationship between the discharge and the ratio of lateral length. Results showed that, the discharge measured was clossed to the discharge calculated along lateral length of $50 \mathrm{~m}$ at operating pressure of one bar.

\section{Friction losses:}

The friction losses in lateral length $\mathbf{5 0}$ and $75 \mathrm{~m}$ for different discharges of 2,4 and $8 \mathrm{l} / \mathrm{h}$ are shown in Fig. (3). that the friction losses in different discharges 2, 4 and $8 \mathrm{l} / \mathrm{h}$ at lateral length $75 \mathrm{~m}$ are bigger than the friction losses in $50 \mathrm{~m}$.

It can be noticed that, the lateral length effect on the friction losses.

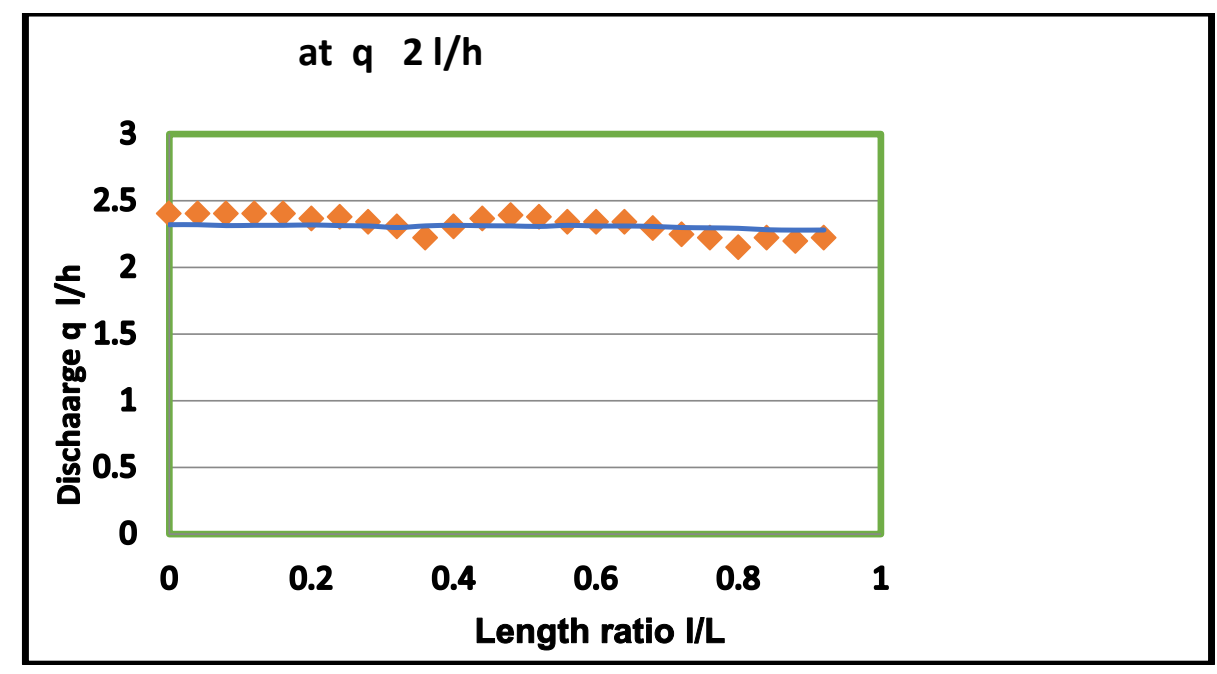

Fig. (2). Discharge along lateral for Katif compensating emitter $2 \mathrm{~L} / \mathrm{h}$ for $50 \mathrm{~m}$ lateral long under pressure of one bar. 
A.H. Gomaa, et al.,

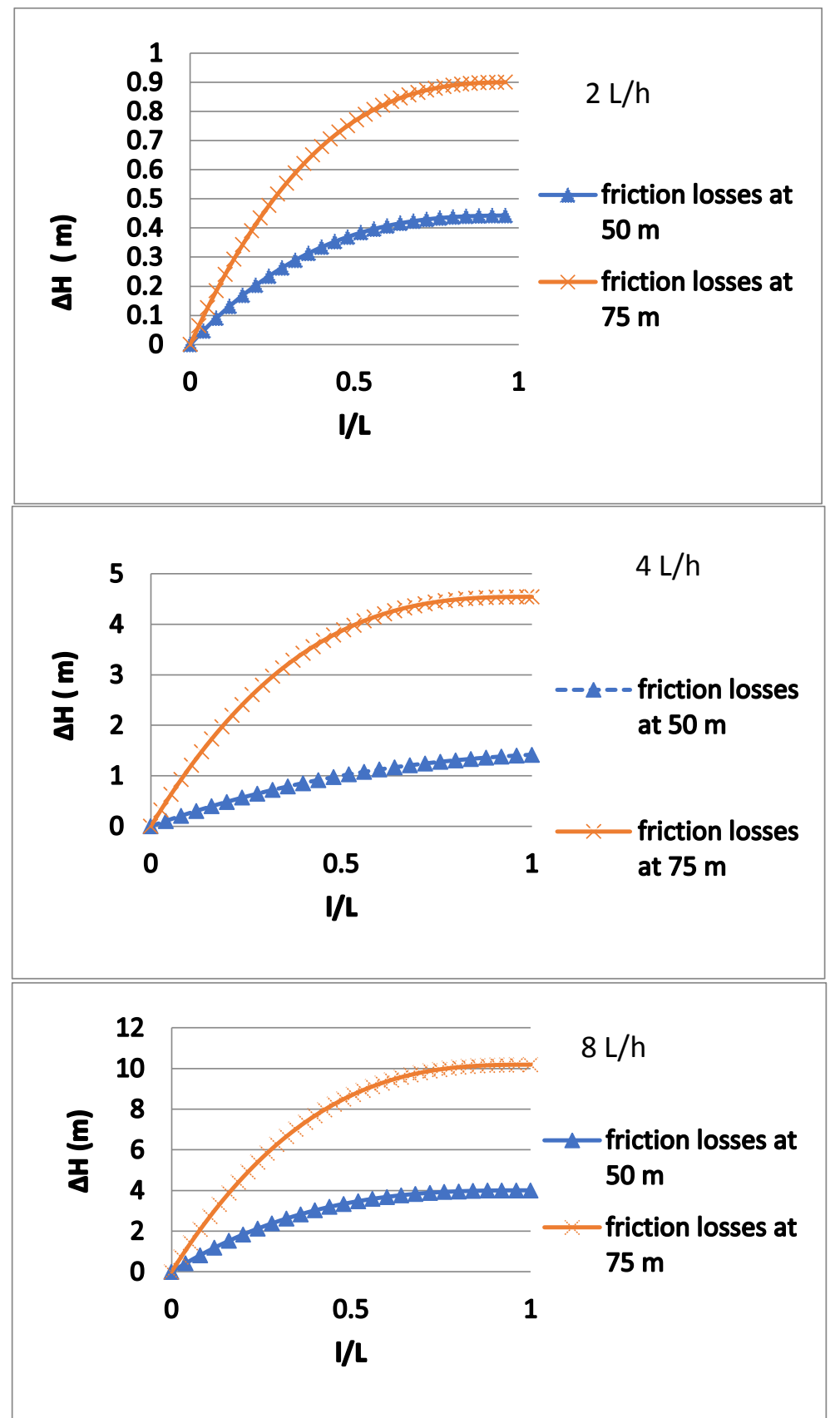

Fig. (3): Shows the friction losses versus length ratio under 2,4 and $8 \mathrm{I} / \mathrm{h}$ and $0.5 \mathrm{~m}$ Katif compensating emitters spacing.

\section{Emission uniformity (EU)\%:}

The best results of the emission uniformity, as shown in Fig. (4), were found under $8 \mathrm{~L} / \mathrm{h}$ which was about $97 \%$. The results are taken four times along laterals.
Data in Tables (2) and (3) show the studied design parameters, such as the friction losses, $(\Delta \mathrm{H})$, coefficient of variations (CV), the emission uniformity, (EU), the discharge measured along lateral $\left(Q_{\text {measured }}\right)$, the discharge determined along lateral( $\left.\boldsymbol{Q}_{\text {determind }}\right)$, q variation and coefficient of uniformity (CU). 


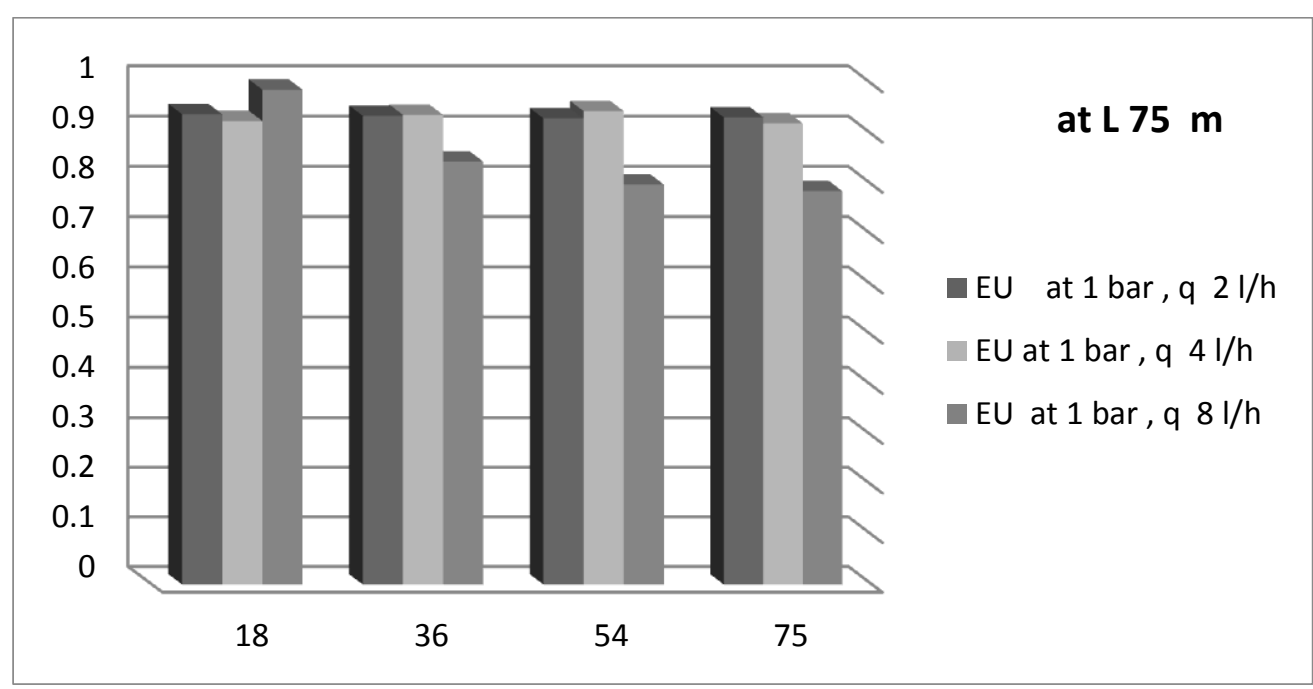

Fig. (4): Show the emission uniformity in pressure one bar at lateral length $75 \mathrm{~m}$

Table (2): Design parameters for $\varphi 13.6 \mathrm{~mm}$ and $2 \mathrm{~m}$ spacing discharges 2.4 and $81 / \mathrm{h}$ and $50 \mathrm{~m}$ lateral length.

\begin{tabular}{|c|c|c|c|c||c||c|}
\hline \multirow{2}{*}{ Design parameters } & \multicolumn{3}{|c|}{1 bar } & \multicolumn{3}{c|}{1.5 bar } \\
\cline { 2 - 7 } & q 2 I/h & q 4 I/h & q $8 \mathrm{I} / \mathrm{h}$ & q 2 I/h & q 4 I/h & q 8 I/h \\
\hline$\Delta \mathrm{H}$ & 0.44291 & 0.70 & 2.22 & 0.44284 & 1.19 & 2.5 \\
\hline $\mathrm{CV}$ & 3.36924 & 4 & 5.09 & 2.11683 & 5.8 & 6.42 \\
\hline EU & 95.7 & 94 & 93.5 & 95.08 & 93.7 & 93 \\
\hline$Q_{\text {measured }}$ & 231.65 & 408.8 & 815.3 & 233 & 423.7 & 823.4 \\
\hline$Q_{\text {determined }}$ & 230.73 & 455.4 & 820.5 & 234.15 & 465.8 & 830 \\
\hline $\mathrm{CU}$ & 97.4 & 96.8 & 95 & 96 & 96.18 & 95.17 \\
\hline$q_{\text {var }}$ & 1.99 & 3.22 & 8.12 & 2.19 & 3.33 & 8.22 \\
\hline
\end{tabular}

Table (3): Design parameters for $\varphi 13.6 \mathrm{~mm}$ and $2 \mathrm{~m}$ spacing under discharges of 2.4 and $81 / \mathrm{h}$ and $75 \mathrm{~m}$ lateral length.

\begin{tabular}{|c|c|c|c|c|c|c|}
\hline \multirow{2}{*}{ Design parameters } & \multicolumn{3}{|c|}{$1 \mathrm{bar}$} & \multicolumn{3}{c|}{$1.5 \mathrm{bar}$} \\
\cline { 2 - 7 } & $\mathrm{q} 2 \mathrm{I} / \mathrm{h}$ & $\mathrm{q} 8 \mathrm{l} / \mathrm{h}$ & $\mathrm{q} 4 \mathrm{l} / \mathrm{h}$ & $\mathrm{q} 2 \mathrm{l} / \mathrm{h}$ & $\mathrm{q} 4 \mathrm{l} / \mathrm{h}$ & $\mathrm{q} 8 \mathrm{I} / \mathrm{h}$ \\
\hline$\Delta \mathrm{H}$ & 0.442911 & 2.89 & .986 & 0.442848 & 1.23 & 3.7 \\
\hline $\mathrm{CV}$ & 3.369242 & 7.2 & 6.17 & 2.116838 & 5.22 & 8.42 \\
\hline EU & 95.7 & 91.5 & 92.2 & 95.08 & 93.6 & 90 \\
\hline$Q_{\text {measured }}$ & 231.65 & 810.3 & 598 & 233 & 0.644 & 813.4 \\
\hline$Q_{\text {determined }}$ & 230.73 & 820.5 & 455.4 & 234.15 & 465.8 & 830 \\
\hline CU & 96.9 & 93.1 & 91.6 & 96.1 & 96.1 & 95 \\
\hline$q_{\text {var }}$ & 1.99 & 8.12 & 3.4 & 2.19 & 3.5 & 8.22 \\
\hline
\end{tabular}


Table (2) showed that the results along lateral $50 \mathrm{~m}$ for three emitters discharge 2,4 and $8 \mathrm{l} / \mathrm{h}$. The friction losses were equal to 0.442 at pressure 1and 1.5 bar for emitter discharge of $2 \mathrm{l} / \mathrm{h}$, equal to .71 and 1.19 at pressure 1 and 1.5 bar for emitter discharge of $4 \mathrm{l} / \mathrm{h}$ and equal to 2.22 and 2.5 at pressure 1 and 1.5 bar for emitter discharge of $8 \mathrm{l} / \mathrm{h}$.

The coefficient of variation were equal to $3.36 \%$ and $2.11 \%$ for emitter discharge of $2 \mathrm{l} / \mathrm{h}$ at pressure 1 and $1.5 \mathrm{bar}$, equal to $4 \%$ and $5.8 \%$ at pressure 1 and 1.5 for emitter discharge of $4 \mathrm{I} / \mathrm{h}$ and equal to $5.09 \%$ and $6.42 \%$ at pressure 1 and 1.5 bar for emitter discharge of $8 \mathrm{l} / \mathrm{h}$.

The emission uniformity (EU) were equal to $95.7 \%$ and $95 \%$ for emitter discharge of $2 \mathrm{l} / \mathrm{h}$ at pressure 1 and 1.5 bar, equal to $94 \%$ and $93.7 \%$ for emitter discharge of $4 \mathrm{l} / \mathrm{h}$ at pressure 1 and 1.5 bar and equal to $93.5 \%$ and $93 \%$ for emitter discharge of $8 \mathrm{l} / \mathrm{h}$ at pressure 1 and 1.5 bar .

The discharge (measured) showed in this table 4for three emitter 2,4 and $8 \mathrm{l} / \mathrm{h}$ at pressure 1 bar equal to $231.3,408.8$ and 815.3 for three emitter and equal to $233,423.7$ and 823 at pressure 1.5 bar .

The discharge (determined) showed in this table 2 for three emitter 2,4 and 8 $\mathrm{I} / \mathrm{h}$ at pressure 1 bar equal to 230.73 ,455.4 and 820.5 for three emitter and equal to $234.15,465.8$ and 830 at pressure 1.5 bar .

The coefficient of uniformity (CU)\% were equal to $97.4 \%$ and $96 \%$ for emitter discharge of $2 \mathrm{l} / \mathrm{h}$ at pressure 1 and 1.5 bar , equal to $96 \%$ and $96.17 \%$ for emitter discharge of $4 \mathrm{I} / \mathrm{h}$ at pressure 1 and 1.5 bar and equal to $95 \%$ and $95.17 \%$ for emitter $8 \mathrm{l} / \mathrm{h}$ at pressure 1 and $1.5 \mathrm{bar}$.

The $q$ variation for emitter $2 \mathrm{l} / \mathrm{h}$ at pressure 1 and 1.5 bar equal to 1.99 and 2.19 , for emitter $4 \mathrm{I} / \mathrm{h}$ equal to 3.22 and
3.33 and for emitter $8 \mathrm{l} / \mathrm{h}$ equal to 8.12 and 8.22 .

Table (3) showed that the results along lateral $75 \mathrm{~m}$ for three emitters 2,4 and $8 \mathrm{I} / \mathrm{h}$. the friction losses were equal to 0.442 at pressure 1 and 1.5 bar for emitter discharge of $2 \mathrm{I} / \mathrm{h}$, equal to .98 and 1.23 at pressure 1 and 1.5 bar for emitter discharge of $4 \mathrm{I} / \mathrm{h}$ and equal to 2.89 and 3.7 at pressure 1 and 1.5 bar for emitter discharge of $8 \mathrm{l} / \mathrm{h}$.

The coefficient of variation were equal to $3.36 \%$ and $2.11 \%$ for emitter discharge of $2 \mathrm{l} / \mathrm{h}$ at pressure 1 and $1.5 \mathrm{bar}$, equal to $7.2 \%$ and $8.42 \%$ at pressure 1 and 1.5 for emitter discharge of $4 \mathrm{I} / \mathrm{h}$ and equal to $5.09 \%$ and $6.42 \%$ at pressure 1 and 1.5 bar for emitter discharge of $8 \mathrm{l} / \mathrm{h}$.

The emission uniformity (EU)\% were equal to $95.7 \%$ and $95.08 \%$ for emitter discharge of $2 \mathrm{l} / \mathrm{h}$ at pressure 1 and 1.5 bar, equal to $92.2 \%$ and $93.6 \%$ for emitter $4 \mathrm{l} / \mathrm{h}$ at pressure 1 and 1.5 bar and equal to $91.5 \%$ and $90 \%$ for emitter discharge of $8 \mathrm{l} / \mathrm{h}$ at pressure 1 and $1.5 \mathrm{bar}$.

The discharge ( $Q$ measured $)$ showed in this Table (3) for three emitter discharge of 2,4 and $8 \mathrm{I} / \mathrm{h}$ at pressure 1 bar equal to $231.6,598$ and 810.3 for three emitter and equal to 233,644 and 813.4 at pressure 1.5 bar .

The discharge $\left(Q_{\text {determined }}\right)$ showed in this Table (3) for three emitter discharge of 2,4 and $8 \mathrm{I} / \mathrm{h}$ at pressure $1 \mathrm{bar}$ equal to $230.73,455.4$ and 820.5 for three emitter and equal to $234.15,465.8$ and 830 at pressure 1.5 bar for emitter discharge 2,4and $8 \mathrm{~L} / \mathrm{h}$, respectively.

The coefficient of uniformity (CU) were equal to $96.9 \%$ and $96 \%$ for emitter $2 \mathrm{l} / \mathrm{h}$ at pressure 1 and $1.5 \mathrm{bar}$, equal to $91.6 \%$ and $96.17 \%$ for emitter $4 \mathrm{l} / \mathrm{h}$ at pressure 1 and $1.5 \mathrm{bar}$ and equal to $93 \%$ and $95 \%$ for emitter $8 \mathrm{l} / \mathrm{h}$ at pressure 1 and $1.5 \mathrm{bar}$. 
The variation discharge $\left(q_{v a r}\right)$ for emitter discharge of $2 \mathrm{l} / \mathrm{h}$ at pressure 1 and 1.5 bar equal to 1.99 and 2.19 , for emitter discharge of $4 \mathrm{I} / \mathrm{h}$ equal to 3.4 and 3.5 and for emitter discharge of $8 \mathrm{I} / \mathrm{h}$ equal to 8.12 and 8.22 .

\section{CONCOLUSION}

The purpose of this study provide water and energy by designing two trickle irrigation systems with compensating emitters (Katif) which have constant discharge with different pressure on zero slope fields based on manufacturing and hydraulic variations. The experiments were carried out in Department of Agricultural Engineering Laboratory and Collage Farm of Faculty of Agriculture, Menoufia University during 2018.

The experiments were designed based on flow variation of total allowable head loss for lateral by sitting a pressure regulator at the beginning of each lateral. Also, based on the emission uniformity that dependent on the coefficient of variation of lateral.

A manufacturing coefficient of variation was calculated based on laboratory test by testing three emitters 2,4 and $8 \mathrm{I} / \mathrm{h}$ at inlet pressure of 1 and 1.5bar . A total, $C V_{t}$ was determined in turn of calculating system uniformity. A field experiment was conducted for $50 \mathrm{~m}$ and $75 \mathrm{~m}$ of lateral length at zero slope for $\varphi 13.6 \mathrm{~mm}$ inner diameter and $16 \mathrm{~mm}$ outer diameter. In addition, spacing between emitters $(2 \quad \mathrm{~m})$ with compensating emitters (Katif) under three different emitter flow rates under inlet pressures of 1 and 1.5 bar.

Friction loss was measured along lateral line and compared to the calculated one. The coefficient of variation of emitter flow rate was found for $50 \mathrm{~m}$ and $\mathbf{7 5} \mathrm{m}$ of drip lateral line on zero slope.

\section{REFERENCES}

Bralts, V.F., D.M. Edwards and I.P. Wu (1987). Drip irrigation design and evaluation based on the statistical uniformity concept Advances in Agronomy, 4: 67-117.

Jensen (1993). "significance of energy losses due to emitter connections in trickle irrigation lines j.irrig.and drainage Div, 119 (5).

Kahiry, M.F., A . El-mesery, F.E. Zabady and M. H. Fayed (2016). Design and evaluation of mobile drip irrigation system. Miser of journal agriculture engineering (33).

Keller, J. and D. Karmeli (1974). Trickle irrigation design parameters Trans. ASAE, 17(4): 678-684.

McConnell, T. (2003). "Trickle irrigation for home gardens extension farm management special list, Kenny. http://www.irrigation/ r/ edu.

Wu, I.P. and H.M. Gitlin (1983). Drip irrigation aplication efficiency and schedules. Trans. ASAE, 28: 92-99.

Wu, I.P. (1992). Energy gradient line approach for direct hydraulic calculation in drip irrigation design. Irrig. sci. 13: 21-29. 
تصميم شبكات ري بالتنقيط ذي النقاطات المعوضة للضغط

أحمد حسن السيد جمعة، أيمن حافظ عيسي، أميرة أحمد محمد عبدالله

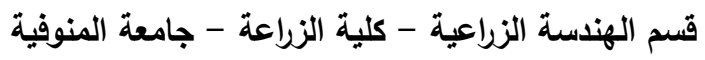

الملخص العربي

الهاف من هذه الاراسة هو تصميم نظام ري بالتقيط ذي النقاطات المعوضة للضغط حيث نفذت هذه التجارب

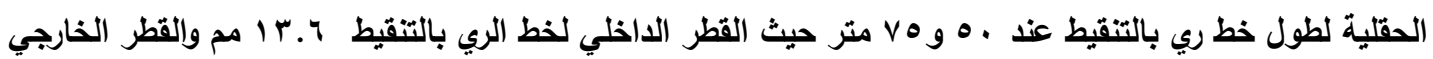

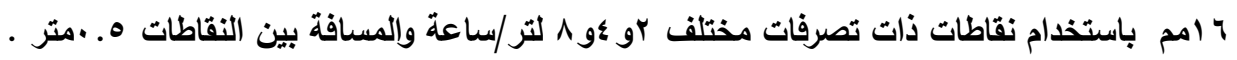

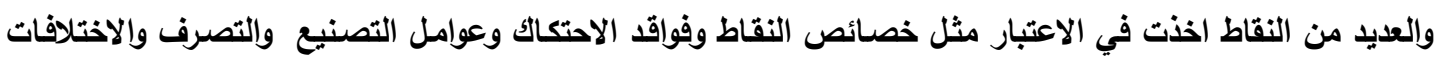

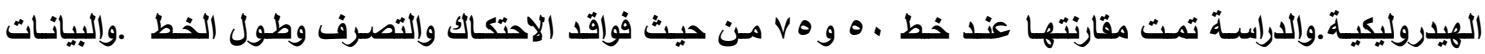

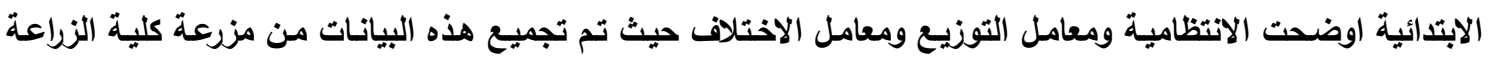
جامعة المنوفية . ومعاملات الاختلاف التصنيعي المقاسـة اوضحت التغير في التصرف للنقاطات واضحت هذه القيم لكل من معامل

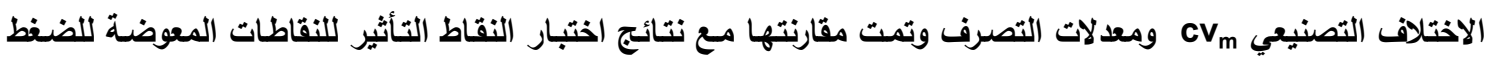

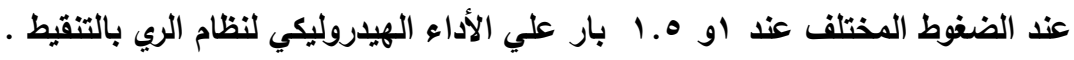

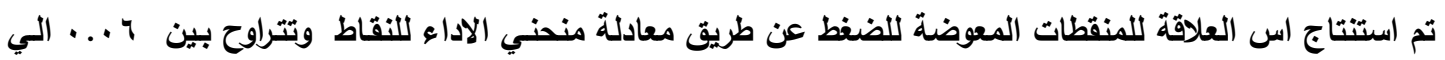

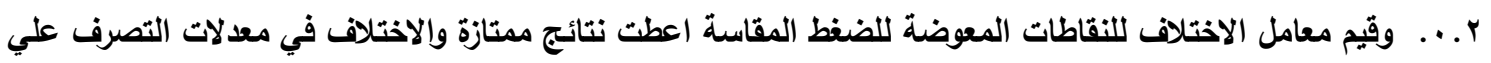

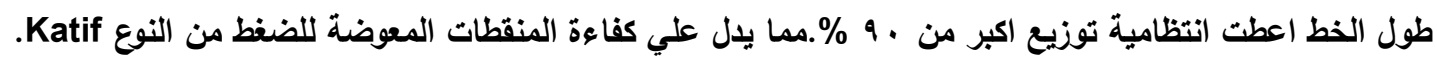

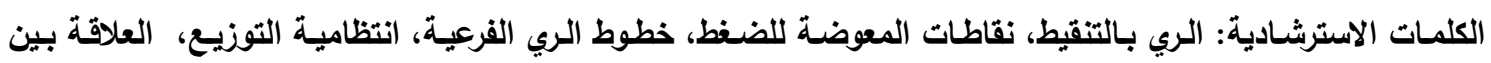
الضغط وإلتصرف. 
